\title{
ASPECTS OF THE FEEDING AND NUTRITIVE VALUE OF LOTUS SPECIES
}

\author{
A. John and J. A. Lancashire \\ Applied Biochemistry Division \\ and Grasslands Division, DSIR, Palmerston North
}

\section{Abstract}

Daily weight gains of sheep in pure sward grazing trials showed relative feeding values to be in the order: white clover (100) > sainfoin (97), Maku lotus (87) > lucerne, red clover (78) > perennial ryegrass (52). The high feeding value of lotus and sainfoin may be due to the presence of condensed tannins which have been shown to improve protein digestion and utilization in indoor feeding trials.

\section{INTRODUCTION}

THERE is a deieloping interest in New Zealand in the use of Lotus species as alternative pasture legumes. 'Grasslands Maku' lotus (L. pedunculatus Cav.) has been found to grow well in moist, hill-country soils of low fertility and low pH (Armstrong, 1974; Brock and Charlton, 1978; Lowther, 1980), whereas the droughtresistance characteristics of $L$. corniculatus make it well suited for dryland pastures (Charlton et al., 1978). Agriculturally important lotus species differ from other pasture legumes grown in New Zealand in that all parts of the plant contain significant amounts of condensed tannins (Ross and Jones, 1974; Jones et al., 1976).

Condensed tannins are of interest because of their ability to form complexes with plant and salivary proteins, which are stable under rumen $\mathrm{pH}$ conditions, and have been implicated as a major reason for the absence of bloating with these legumes (Reid et al., 1974). The production of such a complex with soluble plant proteins has been considered nutritionally important as this would reduce protein degradation to ammonia by rumen microbes and consequently increase amino acid absorption by the animal (Reid et al., 1974; Ulyatt et al., 1977). However, information on the feeding value of fresh lotus species by ruminants is limited to the preliminary results for Maku lotus (Ulyatt et al., 1977) and for $L$ corniculatus in legume-grass pastures and as a hay feed in North America (Seaney and Henson, 1970; Marten and Jordan, 1979). 
This paper reviews recent information from grazing trials and digestion studies with Lotus species, with particular attention to the possible influence of condensed tannins on feeding value. Sainfoin (Onobrychis viciifolia Scop), which also contains condensed tannins (Jones et al., 1976), is included.

\section{FEEDING VALUE' OF LOTUS WITH GRAZING ANIMALS}

Liveweight gain trials using sheep grazing pure swards of several herbage species and cultivars have been conducted. Species included have been Maku lotus, Huia white clover (Trifolium repens L.), Wairau lucerne (Medicago sativa L.), Hamua, Pawera and Red West red clovers (T. pratense L.), Fakir sainfoin and Ruanui perennial ryegrass (Lolium perenne L.). The trials each lasted 6 to 12 weeks and were conducted over spring, summer and autumn periods with weaned lambs or hoggets. All species were rotationally grazed in such a manner as to ensure the animals had an unrestricted diet of leafy, vegetative herbage. Analysis of sward structure before and after grazing indicated these requirements were usually attained.

The in vitro digestibility of herbage judged to be consumed during grazing was $85 \%$ for white clover and lucerne, $83 \%$ for Maku lotus and the red clover cultivars, and $79 \%$ for sainfoin.

As white clover was included in all trials and usually gave the highest weight gain, results shown in Table 1 are presented relative to this species. Weight gain responses with Maku lotus were higher than either lucerne or red clover and inferior only to white clover. Preliminary findings with sainfoin also indicate a high feeding value for this species.

Differences in feeding value of pasture species can arise from differences in feed intake and/or differences in the efficiency of utilization of the consumed feed. For example, the superiority of white clover over ryegrass has been shown to be due to the higher feed intake and the more efficient utilization of protein during digestion of white clover (Ulyatt, 1970; MacRae and Ulyatt, 1974). Herbage intakes were not measured in these trials, therefore it is not possible to conclude whether intake contributed to the higher weight gains with Maku lotus and sainfoin over the other legumes. However, studies with hay feeds have found high-

*Following the definitions recommended by Ulyatt (1973) feeding value $=$ animal response from a given herbage and nutritive value $=$ animal response per unit of feed consumed. 
TABLE 1: COMPARATIVE LIVEWEIGHT GAINS OF SHEEP GRAZING MAKU LOTUS AND OTHER PASTURE SPECIES"

\begin{tabular}{lccc}
\hline & $\begin{array}{c}\text { Liveweight } \\
\text { Relative } \\
\text { Value }\end{array}$ & $\begin{array}{c}\text { Gain } \\
\text { Range } \\
(\mathrm{g} / \mathrm{d})\end{array}$ & $\begin{array}{c}\text { No. of } \\
\text { Trials }\end{array}$ \\
\hline Huia white clover & 100 & $190-354$ & 7 \\
Fakir sainfoin & 97 & $182-230$ & 2 \\
Maku lotus & 87 & $153-315$ & 6 \\
Wairau lucerne & 78 & $123-267$ & 5 \\
Hamua red clover & 78 & $127-234$ & 5 \\
Ruanui ryegrass & 52 & $88-198$ & 4 \\
\hline
\end{tabular}

\footnotetext{
a Keogh and Lancashire, unpublished.

b Determined after fasting.

c Preliminary findings.

${ }^{d}$ Similar values obtained in thrce trials for Pawera and Red West cultivars.
}

er voluntary intakes in comparisons of $L$. corniculatus with lucerne (van Soest, 1965) and of sainfoin with red clover and lucerne (Osbourne et al., 1966).

The superiority of the legumes over perennial ryegrass in Table 1 emphasizes the well-established fact that legumes have a higher feeding value than grasses (Ulyatt, 1970; Ulyatt et al., 1977). However, the occurrence of bloat with the commonly used legumes has generally discouraged the widespread use of specialist legume swards. The use of non-bloating legumes of high feeding value, such as Lotus species, may be one way of overcoming this problem. For instance, Marten and Jordan (1979) have shown that substitution of a pure stand of $L$. corniculatus for one-third of a lucerne-grass pasture system gave a $23 \%$ increase in daily weight gains of lambs. This led to the recommendation of the maximum incorporation of this legume in pastures.

The low current use of Maku lotus and sainfoin in New Zealand appears to be mainly due to the lack of a defined agronomic role for these legumes, although they do appear to be generally limited to those areas where white clover growth is poor. Other papers in this session and recent publications (Lancashire et al., 1980) show that Maku lotus has considerable potential as a major legume constituent in a number of environments, while, $L$. corniculatus appears to be well suited to a wide range of medium fertility dryland soils (Charlton et al., 1978), and sainfoin has shown promise on North Island pumice soils (Percival and McQueen, 1980). The high feeding values of these species suggests that they 
can be valuable as alternative legumes to white clover in these agronomic situations.

\section{NUTRITIVE VALUE OF LOTUS SPECIES}

The chemical compositions of three lotus cultivars and sainfoin are given in Table 2 . The content of crude protein, readily fermentable carbohydrate (soluble sugars and pectin) and of structural carbohydrate (cellulose and hemicellulose) is similar to that of other legumes grown in New Zealand, but the lignin content of lotus species is particularly high, being three to four times that of white clover and red clover (Ulyatt et al., 1977). Lignin is known to depress the overall digestibility of herbages through its inhibitory effect on the digestion of plant cell walls - i.e., cellulose, hemicellulose and lignin (van Soest, 1975) . While the cell wall contents of the fresh herbages in Fig. 1 were similar at about 30 to $35 \%$ of DM, except for white clover at $20 \%$, cell wall digestibility declined as the proportion of lignin in the cell wall increased. As the digestibility of the soluble components of herbages is close to $100 \%$ (van Soest, 1975) the lower organic matter (OM) digestibility of L. corniculatus cultivars of $71 \%$ (Table 2) compared with $85 \%$ for white clover and ryegrass feeds in Fig. 1 can be accounted for by differences in cell wall digestibility. This might have an effect on the voluntary feed intake of animals grazing lotus as reduced OM digestibility has been conrelated with decreased herbage intake of grazing animals (Hodgson, 1977). The lower lignin content 04 leaf than stem suggests that the efficient utilization of lotus swards would involve a grazing management which maximized the intake of leaf rather than stem material.

TABLE 2: CHEMICAL COMPOSITION (\% DM) AND ORGANIC MATTER DIGESTIBILITY OF LOTUS SPECIES AND SAINFOIN.

\begin{tabular}{|c|c|c|c|c|}
\hline & $\begin{array}{l}\text { M aku } \\
\text { Lotus" }\end{array}$ & $\begin{array}{l}\text { Lofus cc } \\
\text { Empire }\end{array}$ & $\begin{array}{l}\text { rniculatus } \\
\text { Maitland }\end{array}$ & $\begin{array}{c}\text { Fakir } \\
\text { Sainfoin' }\end{array}$ \\
\hline Readily fermentable carbohydrate & 13.4 & 14.5 & 17.0 & 19.6 \\
\hline Structural carbohydrate & 17.0 & 19.0 & 17.9 & 20.5 \\
\hline Lignin & 11.6 & 9.9 & 11.4 & 4.8 \\
\hline Crude protein $(\mathrm{N} \times 6.25)$ & 26.7 & 21.8 & 20.5 & 21.3 \\
\hline Condensed tannins ${ }^{d}$ & $2(1-3)$ & 0.25 & 1.45 & $6(5-7)$ \\
\hline Organic matter intake $(\mathrm{g} / \mathrm{d})$ & - & 696 & 699 & 543 \\
\hline Apparent digestibility $(\%)$ & - & 71.3 & 70.5 & 78.1 \\
\hline
\end{tabular}

"Ulyatt et al. (1977).

b Tohn, unpubl. data.

s Ulyatt and Egan (1979).

d Values in parenthesis indicate range (W. T. Jones, pers. comm.), 


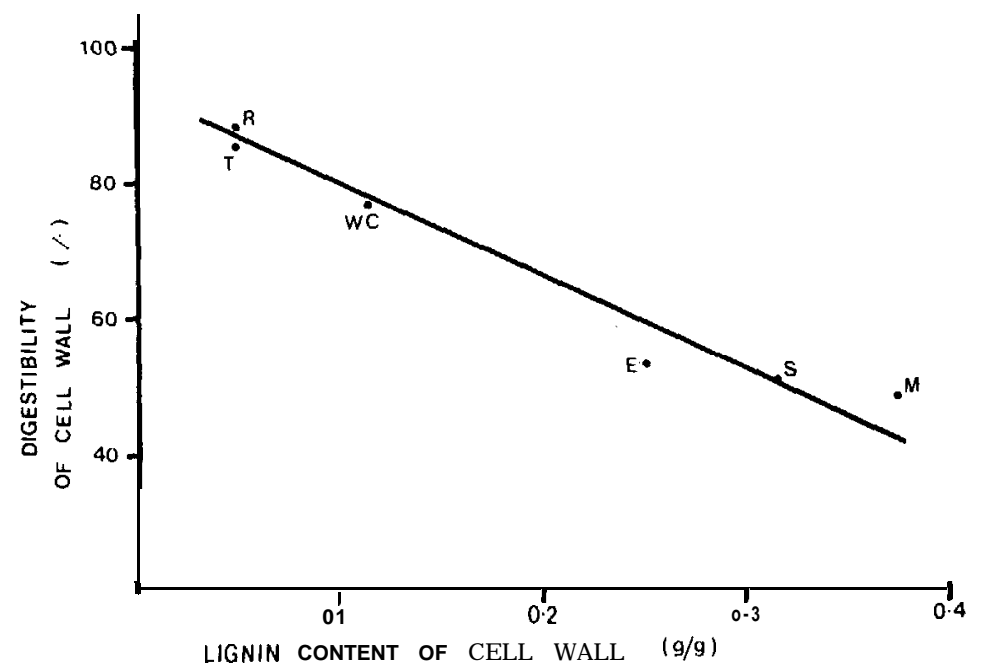

FIG. 1: Effect of lignification on cell wall digestibility of fresh herbages fed to sheep.

Ruanui ryegrass ( R ), Tama ryegrass (T), white clover (W C) and sainfoin (S), calculated from data of Ulyatt and Egan (1979). Empire (E) and Maitland (M) cultivars of L. corniculatus (John, unpubl. data).

\section{CONDENSED TANNINS}

Though the ability of condensed tannins to form stable complexes with soluble plant and salivary proteins in the rumen has been implicated as a major factor in the non-bloating properties of some pasture legumes, the influence of condensed tannins on digestion of fresh herbages is largely unknown. It has been proposed that the formation of these tannin-protein complexes would improve protein utilization during digestion by reducing protein degradation to ammonia in the rumen and subsequently increasing amino acid absorption in the small intestines (Ulyatt et al., 1977).

The identification of two cultivars of $\boldsymbol{L}$. corniculatus differing mainly in condensed tannins content (Table 2) has recently made it possible to study the effects of condensed tannins on digestion. in feeding trials. Data in Table 3 show that the higher level of condensed tannins in the Maitland cultivar was associated with reduced herbage protein solubility, reduced ammonia formation in the rumen, and an increase in feed protein leaving the stomach. These results are consistent with the formation of a plant protein-tannin 
TABLE 3: N DIGESTION AND RETENTION BY SHEEP FED $L$. CORNICULATUS CULTIVARS DIFFERING IN THEIR CONDENSED TANNINS CONTENT

\begin{tabular}{lcc}
\hline & Empire & Maitland \\
\hline Protein solubility (\%) & 95 & 5 \\
Rumen fluid NH,-N (mg/l) & 314 & 228 \\
Rumen OM outflow rate/day' & 1.6 & 1.3 \\
N intake (g/d) & 29.0 & 27.1 \\
N leaving stomach (g/d): & 11.8 & 9.3 \\
$\quad$ Microbial & 11.6 & 14.8 \\
$\quad$ Feed & 23.4 & 23.8 \\
$\quad$ Total & 16.7 & 16.2 \\
N digested in intestines (g/d) & 2.2 & 5.1 \\
N retained (g/d) & &
\end{tabular}

'See Table 2.

b Fraction 1 protein.

'Fractional outflow rate of rumen OM pool estimated from: duodenal $\mathrm{OM}$ flow rate $(\mathrm{g} / \mathrm{d}) \div$ rumen $\mathrm{OM}$ pool size $(\mathrm{g})$.

complex which reduces the rate of protein degradation in the rumen.

Attempts to compare $\mathrm{N}$ digestion in different feeds should take into account differences in turnover rate of rumen digesta as both the quantity of feed protein escaping digestion in the rumen and the yield of microbial protein increase with increasing turnover rate (Kennedy and Milligan, 1978). The passage of protein from the stomach as a function of rumen OM outflow rate for forages of high $\mathrm{N}$ content is illustrated in Fig. 2. It can be seen that at the same OM outflow rate more protein leaves the stomach with feeds of low protein solubility than feeds of high protein solubility. This difference can be accounted for by an increase in feed protein leaving the stomach with low protein solubility feeds (Table 3). These results show that the presence of condensed tannins in lotus reduces the rate of feed protein degradation in the rumen and increases protein flow from the stomach.

Whereas similar amounts of protein were digested in the intestines with the two lotus cultivars, more $\mathrm{N}$ was retained when the sheep were fed Maitland (Table 3). Sainfoin has also been found to yield higher $\mathrm{N}$ retention than white clover or ryegrass (Egan and Ulyatt, 1980). The reason for this higher efficiency of utilization of protein leaving the stomach of sheep fed herbages containing condensed tannins is not known, although differences in urea metabolism have been found (Egan and Ulyatt, 1980). 


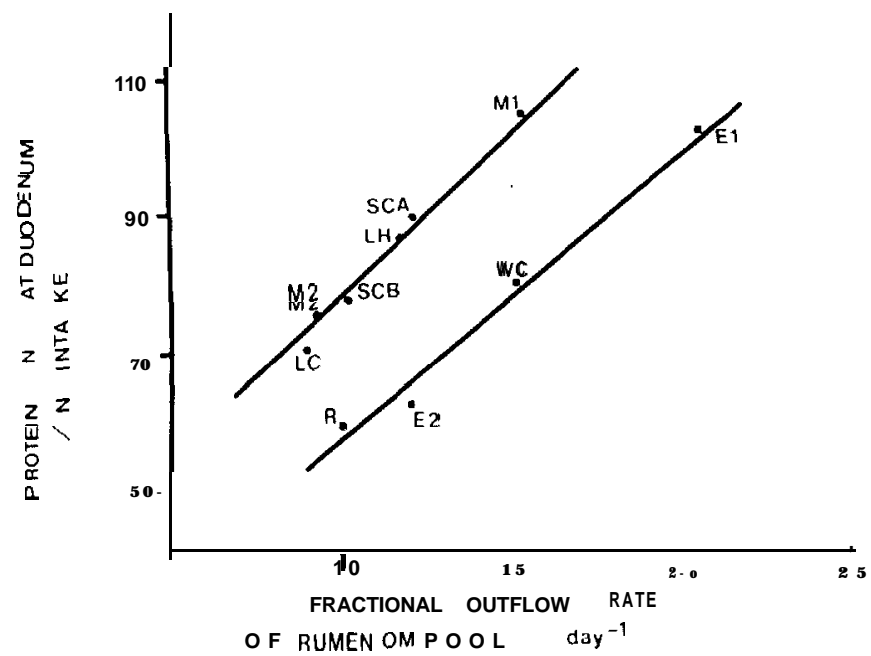

FIG. 2: Passage of protein from the stomach as a function of rumen $O M$ outflow rate for sheep fed forages differing in protein solubility.

Key: High protein solubility feeds (solid squares) : Empire (E) fresh herbage cut at primary harvest (1) and secondary regrowth (2) stages (John, unpubl. data). Ruanui ryegrass (R) and white clover (WC) fresh herbages, data calculated from rumen OM pool size (Ulyatt and Reid, pers. comm.) and the duodenal flow equations of Ulyatt and MacRae (1974) and MacRae and Ulyatt (1974).

Low protein solubility feeds (solid circles): Maitland (Ml and M2) fresh herbage, chaffed lucerne hay (LC) from John (unpubl. data). Subterranean clover (SCA) from Weston and Margan (1979), lucerne hay (LH) and subterranean clover (SCB) from Egan et al. (1975), rumen OM pool size calculated from published rumen water volumes and assuming OM content of $91 \mathrm{~g} / \mathrm{kg}$ digesta.

With regard to OM digestibility, results in Table 2 show that condensed tannins were without effect at the concentration present in Maitland. While concentrations above $8 \%$ of DM may depress digestibility (Burns, 1978) the levels found in lotus and sainfoin are usually lower (Table 2) .

\section{CONCLUSIONS}

Results presented here show that weight gains of sheep grazing Maku lotus and sainfoin are high and close to that of white clover.

While the use of these legumes is at present restricted to certain agronomic situations, it is possible that more widespread adaptation of these species could be achieved in the future as a 
result of plant breeding and selection programmes which are currently in progress (W. Rumball, pers. comm.; J. F. L. Charlton, pers. comm.) . An aspect of nutritional importance which warrants attention during selection programmes is the extent of lignification of the cell walls of these legumes as this was considered here to be a limiting factor in $\mathrm{OM}$ digestion. The presence of condensed tannins in lotus did not affect OM digestion but did improve the digestion and utilization of $\mathrm{N}$. This enhancement of nutritive value by condensed tannins could be one reason for the higher animal performance with Maku lotus than with some other legumes.

\section{REFERENCES}

Armstrong, C. S., 1974. N .Z. Jl exp. A gric., 2: 333-6.

Brock, J. L.; Charlton, J. F. L., 1978. Proc. N.Z. Grassld. A ss., 39: 121-9. Burns, J. C., 1978. J. Dairy Sci., 61: 1809-20

Charlton, J. F. L.; Wilson, E. R. L.; Ross. M. D., 1978: N.Z. '/l exp. Agric., 6: 201-6.

Egan, A. R.; Walker, D. J.; Nader, C. J.; Storer, G., 1975. Aust. J. agric. Ras., 26: 909-22.

Egan, A. R.; Ulyatt, M. I., 1980. J. agric. Sci., Camb., 94: 47-56.

Hodgson, J., 1977. In Animal Production from Temperate Grassland (Ed. B. Gilsenan): 70-5, Irish Grassld \& Anim. Prod. Ass., Dublin.

Jones, W. T.; Broadhurst, R. B.; Lyttleton, J. W., 1976. Phytochemrstry, 15: $1407-\mathrm{g}$.

Kennedy, P. M.; Milligan, L. P., 1978. Br. J. Nutr., 39: 105-17.

Lancashire, J. A.; Gomez, J. S.; McKellar, A., 1980. In Herbage Seed Production. Grassld. Res. \& Pract. Ser. N 0. 1. N.Z. Grassld Ass.

Lowther, W. L., 1980. N.Z. $/ l$ exp. Agric., 8: $131-8$.

MacRae, J. C.; Ulyatt, M. J., 1974. J. agric. Sci., Camb., 82: 309-19.

Marten, G. C.; Jordan, R. M., 1979. A gron. J., 71: 55-9.

Osbourne, D. F.; Thompson, D J.; Terry, R. A, 1966. Proc. 15th int. Grassld Congr.: 363-7.

Percival, N. S.; McQueen, I. P. M., 1980. Proc. Agron. Soc. N.Z., 10:

Reid, C. S. W.; Ulyatt, M. J.; Wilson, J. M., 1974. Proc. N.Z. Soc. Anim. Prod., 34: 82-92.

Ross, M. D.; Jones, W. T., 1974. N.Z. Jl agric. Res., 17: 191-5.

Seaney, R. R.; Henson, P. R., 1970. A dv. Agron., 22: 119-57.

van Soest, P. J., 1965. J. A nim. Sci., 24: 834-43.

1975. In Digestion and M etabolism of the Ruminant. (Eds. I.

W. McDonald and A. C. I. Warner) : 351-65. Univ. New England Publ. Unit, Armidale.

Ulyatt, M. J., 1970. Proc. N .Z. Grassld A ss., 32: 61-B.

1973. In Chemistry and Biocheniisfry of Herbage. Vol. 3, (Eds.

G. W. Butler and R. W. Bailey): 131-78. Academic Press, London.

Ulyatt, M. J.; Egan, A. R., 1979. J. agric. Sci., Camb. 92: 605-16.

Ulyatt, M. J.; Lancashire, J. A.; Jones, W. T., 1977. Proc. N.Z. Grassld Ass., 38: 107-18.

Ulyatt, M. J.; MacRae, J. C., 1974. J. agric. Sci., Camb., 82: 295-307.

Weston, R. H.; Margan, D. E., 1979. dust. J. agric. Res., 30: 543-9. 